\title{
High efficiency production of substitute natural gas from biomass
}

\author{
L.P.L.M. Rabou
}

Published in ScienceDirect, Vol. 111-112, pp. 456-460, January 2012 